\title{
Family Support in Overcoming of Restrainting People with Mental Disorders in Ogan Ilir Regency
}

\author{
Nurkholis Buhori ${ }^{1}$, Fenny Etrawati ${ }^{1, *}$ \\ ${ }^{1}$ Public Health Faculty, Universitas Sriwijaya Indralaya, Indonesia \\ *Corresponding author. Email: fenny_etrawati@gmail.com
}

\begin{abstract}
Based on Rikesdas (2013), in South Sumatra there were $14.4 \%$ people with mental disorder has been put on a restrainted at and In Ogan Ilir Regency found that 24 people that has been restrainted. This study aimed to find out family support to the restrainting people with mental disorders in Ogan Ilir Regency. This study was used qualitative approach and the sample took purposively with the appropriateness and adequacy criteria. The key informants were 5 patient's family, 6 health officers and 6 village stakeholders. The Researcher used triangulation techniques to validate the data then analyzed it with content analysis. The results indicated that the family giving physical handling for daily needs (ex: feeding, bathing, replacing clothes) to patients with mental disorders (ODGJ) but some of them were not given medication. The family were worried the patient will relapse and disturb the community so some of them being restrainted. Close relatives suggested taking them to the hospital and seeking alternative treatment also build a positive thinking and accepting reality as a fate. In conclusion the health officers need to socialize and educate the patients family how to treat and and handling people with mental disorder without discrimination (restrainting them).
\end{abstract}

Keywords: family support, people with mental disorders, restraints

\section{INTRODUCTION}

The World Health Organization (WHO) states that from the statistical data reported there are around 450 million people in the world experiencing mental health problems, where one third of them occur in developing countries [1]. The World Health Organization (WHO) also mentions that there are around 35 million people affected by depression, 60 million people affected by bipolar affective, 21 million people affected by schizophrenia, and 47.5 million affected by dementia [2]. Furthermore the World Health Organization (WHO) (2016) says that Schizophrenia is a severe mental illness affecting more than 21 million people in the world.

The results of a health survey in Indonesia in 2013 showed that there were 1.7 per 1,000 Indonesians suffering from schizophrenia [3]. It is known that more than 57,000 people with disabilities have psychosocial health conditions, at least once in their lives have been locked up - shackled or locked up in a room [4]. Among the registered patients, approximately $14.8 \%$ had been confined in their lifetime. In the Health Research and Development Agency, which was reported by Riskesdes in 2013, the percentage of households that had severe mental illness that had ever been installed in South Sumatra was still very high at 14.4 percent. This number occupies the 3rd position, where the 2nd and 1st positions are respectively occupied by DKI Jakarta and Central Kalimantan from all provinces in Indonesia.

Emotional support in the form of sympathetic support and empathy from the family is needed in providing an understanding of ODGJ so they do not feel burdened alone [5]. According to Butar, the family is the closest person to the patient who has an important role in healing the patient, one of which is informative support in the form of communication and shared responsibility [6]. The family as a sub-system unit in the community certainly plays a central role in the care of members of the community, including for members who experience mental disorders [7].

Based on data obtained from the Health Office of South Sumatra Province, it is known that Ogan Ilir Regency ranks 7th out of 17 districts / cities in South Sumatra Province with the highest number of people with mental disorders in dipungung[8]. In addition, from December 2016 to December 2017 there were no significant changes in the free-fitting pasung in Ogan Ilir, which amounted to 24 people with mental disorders who were put in prison. Therefore, the researcher wants to explore further about family support for overcoming the mounting of people with mental disorders in Ogan Ilir district.

\section{METHOD}

This study uses qualitative research, which is research that uses techniques specifically to obtain in-depth information or answers about a person's perceptions, opinions, and feelings. The study was descriptive in nature, describing a comprehensive and detailed picture of the events. Descriptive data in the form of written or oral words from people and behaviors that can be observed, using a phenomenological approach in which the researcher interprets, interprets the results of his research. Determine 
the location of the village research that there are people with mental disorders in Tabedak Village, Talang Sleman and Sukaraja Lama Village. The source of the informants in this study is the subject from which the data was taken. Collecting information or data using in-depth interviews (indepth interview) and observation so that the subject responds and answers questions verbally and through observation. Intake of informants in this study was carried out using purposive sampling techniques selected based on specific considerations and goals made by the researcher. Key informants came from 3 villages in Kecamatan Payaraman and Tebing Grinting consisting of 3 family representatives of patients with mental illness (ODGJ) who were put in and 2 families of patients with mental illness (ODGJ) patients who were not fitted. Key expert informants consisted of 1 health officer from each village, 1 person from the Ogan Ilir District Health Service officer, 1 health worker from each subdistrict health center and 2 community leaders from each village. Total informants were 17 people, consisting of 5 family key informants and 6 health professional key informants and 6 expert key informants. Community leaders.

\section{RESULTS AND DISCUSSION}

Family knowledge in handling ODGJ mostly takes care of people who are sick in general, namely in the form of physical handlers by feeding, replacing clothes and bathing with wet towels. Some of the patients were given cigarettes. Other patients' families conveyed their knowledge regarding the management of ODGJ, among them there was a lack of understanding about the management of ODGJ, but in terms of treatment it was already quite a lot done. The family of the ODGJ patient initials KK stated that the ODGJ patient was no longer treated because he was considered healthy. And from what ODGJ patients look in the family is known to look like a "less" person. Families of ODGJ patients whose initials KK also convey that ODGJ patients in the family are rarely treated. Health workers more giving outreach by emphasizing the provision of knowledge to families in the form of giving medicines to ODGJ patients regularly and continuously, self-care, and personal hygiene. Giving the drug is done so that ODGJ patients can achieve calm conditions and in the next stage can continue to improve, then these patients can be released.

Table 1. Family Knowledge in Overcoming People with Mental Disorder

\begin{tabular}{|c|c|c|c|c|c|}
\hline \multirow[b]{2}{*}{ Informants } & \multicolumn{5}{|c|}{ Knowledge in Overcoming People with Mental Disorder } \\
\hline & Restrainting & $\begin{array}{c}\text { Not } \\
\text { Restatrainting }\end{array}$ & $\begin{array}{l}\text { Physical } \\
\text { handling }\end{array}$ & $\begin{array}{l}\text { Rarely } \\
\text { treated }\end{array}$ & $\begin{array}{l}\text { Often } \\
\text { treated }\end{array}$ \\
\hline KZ & $\sqrt{ }$ & & $\sqrt{ }$ & & \\
\hline KM & $\sqrt{ }$ & & & & $\sqrt{ }$ \\
\hline KH & & $\sqrt{ }$ & $\sqrt{ }$ & & \\
\hline $\mathrm{KE}$ & & $\sqrt{ }$ & $\sqrt{ }$ & & \\
\hline KK & $\sqrt{ }$ & & & $\sqrt{ }$ & \\
\hline
\end{tabular}

Source: Primary Data, 2018

In responding to ODGJ family members, especially from patients who were not put in pairs, the family said that it was normal to face a family with a mental disorder. That is because one of the two patients has experienced a mental disorder since childhood, and one of the others did not disturb the community. The other family gave mixed opinions in responding to family members who experienced ODGJ, including being resigned to what happened to their family (ODGJ patients), other stated that they could only be patient with the disease that had been experienced by ODGJ patients. The family assessed that the surrounding community was afraid of their child who was an ODGJ patient because if he went out, it was feared that it would cause problems and rage. 
Table 2 Family Attitude toward People with Mental Disorders

\begin{tabular}{|c|c|c|c|c|c|}
\hline Informants & Restrainting & Surrender & Patient & $\begin{array}{l}\text { Afraid of } \\
\text { relapse } \\
\text { condition }\end{array}$ & Indifferent \\
\hline KZ & $\sqrt{ }$ & & $\sqrt{ }$ & & \\
\hline KM & $\sqrt{ }$ & & & & $\sqrt{ }$ \\
\hline $\mathrm{KH}$ & & $\sqrt{ }$ & $\sqrt{ }$ & & \\
\hline $\mathrm{KE}$ & & $\sqrt{ }$ & $\sqrt{ }$ & & \\
\hline KK & $\sqrt{ }$ & & & $\sqrt{ }$ & \\
\hline
\end{tabular}

Source: Primary Data, 2018

Health workers said that families, including the community, in dealing with ODGJ patients generally behaved normally and were not overreacted. Religious leaders also said that the community when there are ODGJ patients responding naturally or commonly occur in the community.

Emotional support provided by families to ODGJ patients was to provide care, food, help to take care of patients well and given treatment. There was also a form of not fighting ODGJ patients when they were angry. Some informants said that the form of attention and care given by close relatives was in the form of feelings of sympathy for ODGJ patients as well as for family resource persons. It also added that all the flaking flavors were still stored. The ones who take care of ODGJ patients are their sisters and family since the patient was child.

Regarding the support and attention given by the village head to families and ODGJ patients, it was conveyed that the head of village paid less attention. The head of village only recorded and had given his advice that the disease had become a part or fate of the patient. Beside that, The care given by health workers to families and mental ODGJ patients, including health workers proposing various kinds of assistance in the form of social and non-social. The emphasis on continuing to take medication and delivering medicine to patients is a top priority for health workers in providing a form of care. As a form of care given to patients, religious leaders are very concerned about what is experienced by ODGJ patients, it makes the religious leader not discriminate them with normal people and often give money and food.

Most of the informants who came from families said that close relatives did not provide advice or informative support. Other said that close relatives giving advice to remain patient, there were also those who suggested taking him to the hospital and seeking alternative treatment. Health workers focus more on suggestions and advice in the form of routine, timely, and reported medication that is used up. In addition, officers also conveyed to pay more attention to ODGJ patients both in terms of personal hygiene, social interaction and involvement in community activities. The patient's family is also asked to remain sabbaths and trust in what is suffered by the patient. Quite diverse from other informmant, community leader was providing advice and information to keep thinking positive and accepting it as a destiny from The Almighty God. There were also community leaders who don't talk much and interact with the families of ODGJ patients for fear of offending the family's feelings.

\section{DISCUSSION}

Family understanding and knowledge is only limited to the handling and management of personal hygien and do regular treatment, although the officers have conducted socialization related to how the correct and proper handling of ODGJ patients, some people still do not understand well the importance of drug administration to ODGJ patients. What's more there are also families of patients who have stopped giving drugs to ODGJ patients. From the health workers themselves, the officers gave more socialization that focused on giving knowledge to families in the form of giving medicines to ODGJ patients routinely and continuously, self-care, and personal hygiene. Giving the drug is done so that ODGJ patients can achieve calm conditions and in the next stage can continue to improve. And if previously put in a pail, the patient can be freed from confinement.

This is in accordance with Sulastri's findings that the family considers that if the symptoms diminish it means the patient has recovered so there is no need to administer medication[8]. The family still doesn't understand about controlling hallucinations. The family also thinks that if the patient is not dangerous then there is no need to worry. 
Sulastri, added that the ability to treat mental patients is relatively low or inadequate.

According to researchers lack of optimalizing in handling of the family makes healing process for ODGJ were not going well, especially there was also families of patients who have stopped giving drugs to ODGJ patients. Understanding that conditions makes these patients still often relapse and show disturbing behavior in the community. Health workers who provide information in handling ODGJ in the form of regular and consistent drug administration need to monitor the implementation of drug administration so that what was conveyed could go well. The right and proper understanding of the family will make the condition of ODGJ patients better and undesirable things can be prevented.

Attitude is defined as the reaction or response of someone who is still closed to a stimulus or object. The manifestation of one's own attitude cannot be directly seen, but it can only first interpret the closed behavior[9]. The results of this study indicate that family attitudes in responding to ODGJ patients can only be patient and resigned to accept everything that happens. In addition, it is also known that there are some family resource persons who are mediocre in responding to ODGJ patients, considering that the patient has experienced the disease since childhood. There was also a family resource person who said there were concerns that ODGJ patients would commit acts of violence and could even kill people if they left the house.

According to Kaakinen et.al, actions and family acceptance of sick people is done as a form of family support for ODGJ patients[10]. In addition, family members with problems will mark that their families provide support and are always ready to provide help and assistance if needed. Research conducted by Lestari et. al. in seeing the tendency or attitude of families of people with mental disorders towards pasung actions, it was concluded that the majority of families of people with mental disorders who come to the psychiatric clinic RSJ have antipathy and do not support the act of retention. This happens because families feel sorry, torture and of course doing restrainting "pasung" will not be able to cure ODGJ patients, and even that can hurt and make ODGJ unable to move freely [11].

The attitude of family resource persons who can only surrender and be patient towards those experienced by ODGJ patients, is caused by the views of families who have made every effort in facilitating health care for ODGJ patients. The attitude of ODGJ patients, which is difficult to control when experiencing a relapse condition, makes family speakers more concerned about ODGJ patients if they are left home alone. In addition, ODGJ patients who have long suffered from the disease and experience unstable healing despite various efforts have been made, making the family more resigned and surrender everything that happens to the Almighty.

More than 80 percent of students who participated in this study have never participated in a formal socialization related to cigarette content but one third of the total respondents obtained this information via internet and from their teachers through teaching and learning process. More than 60 percent are exposed to smoking environments. Nicotine is the cigarette ingredient most widely known by students. In contrast, most respondents did not know that Nepheline, Butane, Arsenic and Hygrazine were also contained in cigarettes. So, further socialization is needed regarding cigarette ingredients that are harmful to the body.

Emotional support provided by close relatives of ODGJ patients is manifested through the provision of care, food, assistance in taking care of patients well and given treatment. There was also a form of ODGJ patients not opposed when they are angry and good empathy in ODGJ patients. Regarding the support and attention given by the village head to families and ODGJ patients, it was conveyed that the village head paid less attention. Besides that, there are some village heads who don't stay at home.

The form of care given by health workers to families and mental ODGJ patients, including health workers proposing various kinds of assistance in the form of social or nonsocial, such as providing assistance in making National Health Insurance so that ODGJ patients can seek treatment accordingly. In addition there is an emphasis made by health workers on the continuation of continuing to take medication and delivering drugs to patients. And this is a top priority for health workers in providing a form of care. While the emotional support given by religious leaders to patients, namely a deep concern for what is experienced by ODGJ patients, therefore these religious leaders in treating ODGJ patients are not discriminatory and discriminate with normal people. In addition, these community leaders often provide food and money to ODGJ patients.

Ullatifah in his research stated that family support is needed by people with mental disorders to motivate them during care and treatment before deciding to install[12]. Suharto's research results also state that family support is very important to support the release of ODGJ so they do not live in isolation [13]. In addition, in line with the findings of Laksmi and Henderiyanto, a positive outlook was also raised by the environment to family members of ODS and ODS when they knew the conditions and conditions of ODS. Positive views received are acceptance, empathy, understanding, and accepting conditions from ODS family members [14].

Community leaders, especially those from some head of village did not pay much attention to the people who experience mental disorders. This can be seen from some village heads who are difficult to find because they are not at home. In addition, some of the village heads delegated their authority to the village secretariat so that they were seen to be disengaged from problems related to ODGJ patients who were put in prison. Likewise, when conducting interviews, some village heads said that they did not understand the problems that occurred. Whereas support from all parties is absolutely necessary in order to speed up the healing process as well as to ease the burden borne by ODGJ families.

Informative support provided by diverse families is close, some provide advice to remain patient - and because of that advice the resource person can stay strong in the face 
of the harsh reality that occurs, suggest to enter the hospital who knows can be healthy and can speak fluently, and suggest to try treatment at alternative treatments so you know what causes mental disorders. The responses given are quite diverse too. There is a form of gratitude, some are hesitant to follow and some are listened well but not followed. In terms of informative support, health workers focus more on suggestions and advice in the form of routine, timely, and reported medication that is used up. In addition, officers also conveyed to pay more attention to ODGJ patients both in terms of personal hygiene, social interaction and involvement in community activities. The patient's family is also asked to remain patient and trust in what is suffered by the patient.

The advice and advice given by community leaders in the families of ODGJ patients is quite diverse. Some of them provide advice and information to keep thinking positive and accept the fact that the conditions experienced today are a letter of destiny from Almighty God. There are also other community leaders who are more inclined to not talk much and interact with the families of ODGJ patients on the grounds that the family concerned may be offended.

In line with the results of research conducted by Eni and Hendiyanto that families provide advice, suggestions or responses to help ODGJ patients in the recovery process[15]. Information provided by the family during the recovery process and maintaining recovery conditions in ODGJ patients such as reminding them to take medicine, control to the doctor / hospital and carry out activities to support the recovery condition in ODGJ. Lestari, et al. (2014) in his study added that the recovery process can run smoothly if there is support from various parties, especially from health workers. ${ }^{11}$ Relevant to the research conducted by Eni and Herdiyanto that community leaders have a role in three aspects, including cognitive, affection, and conative aspects. The cognitive aspect is the discovery of the views of traditional leaders towards ODGJ and their families. The aspect of affection is characterized by feelings of sadness and concern experienced by traditional leaders about the stigma given to ODGJ. The conative aspect is shown through what traditional leaders know about the views on ODGJ.

In the advice given by close relatives of the family of informants, there is advice or advice that advocates the treatment of ODG patients for facilitation of health through alternative medicine (non-medical or traditional healers) on the grounds that ODGJ patients can be identified the main causes of mental disorders as well as to be cured immediately. This happens because there is still a wrong understanding in responding to ODGJ patients. Although the amount is small, the wrong understanding in responding to ODGJ patients must be addressed immediately so that the handling of ODGJ patients will be better and optimal going forward. In addition, from opinions expressed by community leaders, the presence of ODGJ patients in the midst of the community is no longer a negative stigma for the community, but instead gradually improves.

\section{CONCLUSION}

Families do not support the handling of ODG patients in the pasung, causing the optimization of treatment for ODGJ patients as well as causing disruption and threat to public safety, thus impacting on retention behavior that is still carried out by the family. Ogan Ilir District Health Office is expected to increase socialization and education, and collaboration of all levels of society. The advice that can be given is the Ogan Ilir District Health Office is expected to increase socialization and education, also collaboration of all levels of society including village officials.

\section{REFERENCES}

[1] World Health Organization, "Mental health : new understanding, new hope," Switzerlan, 2012.

[2] World Health Organization, "Improving health system and service for mental health: who library catologuing- in- publication data," Switzerlan, 2016.

[3] Indonesian Ministry of Health, "Basic health research,” Jakarta, 2013.

[4] Human Rights Watch, "Living in hell: violence against people with psychosocial disabilities in Indonesia," Jakarta, 2016.

[5] Harnilawati, The concepts and processes of family nursing. South Sulawesi: Pustaka As Salam, 2013.

[6] D. Khairunisa, "The correlation between family knowledge with the obedience on medicine's consumption of schizophrenia's outpatient of Prof. M. Ildrem Medan Mental Hospital," Universitas Muhammadiyah Sumatera Utara, 2016.

[7] M. Astuti, "The condition of people with mental illness pasung, family and community environment in 50 city districts," Sosio Concept., vol. 6, no. 3, pp. 256-268, 2017.

[8] South Sumatra Provincial Health Office, "Health profile-disease prevention and control section (P2P) mental health," Palembang, 2016.

[9] Sulastri, "The ability of families to care for people with mental disorders.," J. Kesehat., vol. 9, no. 1, pp. 131137, 2018.

[10] J. Kaakinen, V. Duff, D. Coehlo, and S. Hanson, Family health care nursing. United States of America: F.A Davis Company, 2010.

[11] M. Lestari P, Choiriyyah Z, "The tendency or attitude of families of people with mental disorders towards pasung (case study at Amino Gondho Hutomo 
Semarang Hospital)," J. Keperawatan Jiwa, vol. 2, no. 1, pp. 14-23, 2014.

[12] U. W. Annisa, "Relationship of family psychosocial support with schizophrenia length of stay in Surakarta Regional Mental Hospital," Universitas Muhammadiyah Surakarta, 2015.

[13] B. Suharto, "Pasung culture and sociological juridical impact (study of pasung liberation \& prevention of mounting actions in Wonogiri Regency)," IJMSIndones. J. Med. Sci., vol. 1, no. 2, pp. 1-10, 2014.

[14] I. A. W. C. Laksmi and Y. K. Herdiyanto, "The process of accepting family members of people with schizophrenia," J. Psikol. Udayana, vol. 6, no. 1, pp. 859$872,2019$.

[15] K. Y. Eni and Y. K. Herdiyanto, "Family social support for the recovery of people with schizorenia (ODS) in Bali," J. Psikol. Udayana, vol. 5, no. 3, pp. 486-500, 2018. 